\title{
Estimation of soil fertility map of Makhamalabad farm, Nashik, Maharashtra (India)
}

NIRMALA JADHAV, ANIL RATHOD AND VRUSHALI KHOMANE

Received : 30.11.2012; Accepted : 29.05.2015

MEMBERS OF RESEARCH FORUM:

Corresponding author : NIRMALA JADHAV, Department of Soil Science and Agricultural Chemistry, K.K. Wagh College of Agricultural Engineering and Technology, NASHIK (M.S.) INDIA Email: nvjadhav@kkwagh.edu.in

Co-authors :

ANIL RATHOD, Dr. D.Y. Patil College of Agricultural Engineering, Talsande, KOLHAPUR (M.S.) INDIA

VRUSHALI KHOMANE, Sadaguru College of Agriculture, Mirajgaon, AHMEDNAGAR (M.S.) INDIA

Email: khomanevrushali8@gmail.com

\section{Summary}

For the efficient utilization of soil and water resources, soil testing of such farm was carried out in Nashik. Makhamalabad farm for providing comprehensive information was characterized. Representative soil samples from each of forteen plots of Makhamalabad farm were collected. The soil survey of representative area was completed by plane table survey method. The soil samples were tested in laboratory for determining various soil properties viz., soil $\mathrm{pH}$, soil electrical conductivity, soil colour, available moisture content and soil nutrients like organic carbon content, soil calcium carbonate, available nitrogen, available potassium and available phosphorus. The chemical analysis of soil will measure the nutrient status of the soil and serve as a guide to profitable use of fertilizers and recommendation of crops. A standard soil fertility map is a two dimensional document presented on a paper or on various other kind of supports and gives greatly reduced, simplified pictures of the spatial organization of soils in the natural environment showing the soil properties and available soil nutrients. The work is carried out for preparation of soil fertility map of Makhamalabad farm which belongs to K.K. Wagh Education Society, Nashik. The Makhamalabad farm is situated in the Makhamalabad shivar, Nashik. The area of farm was about 9.31 ha. There are 14 plots in the farm.

Key words : Soil fertility, Soil properties, Soil survey, Sampling

How to cite this article : Jadhav, Nirmala, Rathod, Anil and Khomane, Vrushali (2015). Estimation of soil fertility map of Makhamalabad farm, Nashik, Maharashtra (India). Asian J. Soil Sci., 10(1) : 162165. 